\title{
自己免疫性膵炎に合併する膵仮性囊胞の形成機序と ステロイドの有用性について
}

\section{一自験例 12 症例における検討一}

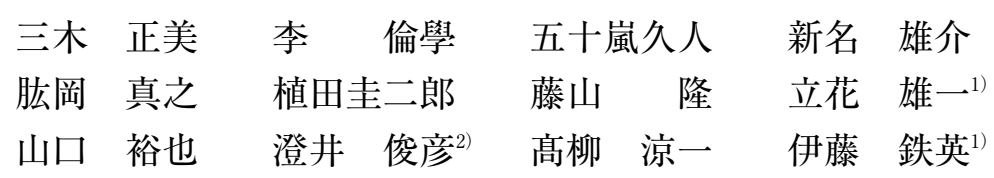

要 旨：膵仮性囊胞を合併した自己免疫性膵炎（AIP） 12 症例をもとに, 膵仮性囊胞の形 成機序とステロイドの有効性について検討した，膵仮性囊胞の発生部位は全例膵体尾部で あり，10 例の $83 \%$ に膵管狭細化に伴う閉塞性膵炎を認めた．膵酵素上昇 $(75 \%)$ および腹 痛（50\%）も高率に認めた，ステロイド治療により膵仮性囊胞は全例で消失し，膵管狭細 像および閉塞性膵炎像も改善した，さらに，膵酵素上昇および腹痛も全例で改善した，以 上より，AIP に合併する膵仮性囊胞の形成機序は閉塞性膵炎に起因するものであり，AIP に合併する膵仮性囊胞には閉塞性膵炎の解除を目的としたステロイド投与は有効であっ た. AIP の疾患概念が発信された当初は, 閉塞性膵炎および膵仮性囊胞の合併は稀と考え られていたが, 今回の検討から膵仮性囊胞の診療においては AIP の可能性も念頭に置いた 的確な診断と治療法の選択が重要と考えられた.

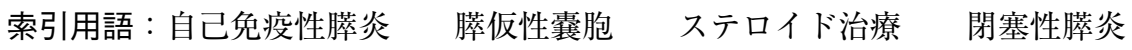

\section{はじめに}

自己免疫性膵炎 (Autoimmune pancreatitis : AIP) は, 1995 年に本邦から発信された疾患概念 ${ }^{1)}$ で，その発症に自己免疫的機序が関与する膵の炎 症性疾患である.典型的にはびまん性の膵腫大 ${ }^{2}$ や 膵管狭細像 ${ }^{3)}$ といった画像所見や血清 IgG4 高值 を呈し ${ }^{4)}$, ステロイドが著効する ${ }^{2.5)}$. 黄疸や血糖コ ントロールの悪化で発症することが多く ${ }^{6)}$, 急性脺 炎様の腹痛発作や膵酵素上昇を認めることは稀で ある7).

一般に, 膵癌や慢性膵炎に合併する膵管狭窄病 変は, 膵液うっ滞による尾側膵管の拡張や膵管内

\footnotetext{
1) 九州大学大学院医学研究院病態制御内科

2) 国立病院機構小倉医療センター消化器内科 $<$ 受理日：平成 26 年 4 月 1 日 $>$
}

圧上昇に伴う膵酵素上昇・疼痛発作を認めること が多く ${ }^{8)}$, 時に膵管破綻による膵仮性囊胞を形成す る ${ }^{9)}$. 一方, AIP の概念が発信された当初は, 狭細 部の尾側膵管は拡張せず ${ }^{10)}$, 膵仮性囊胞は合併し ないとされてきたが1), 症例の蓄積とともに膵仮性 囊胞を合併した AIP 症例の報告も散見されるよ うになってきたものの ${ }^{11 \sim 19)}$, その形成機序は不明 である。治療法に関しても, 慢性膵炎に合併した 膵仮性囊胞に対しては 2009 年にガイドライン ${ }^{20)}$ が作成されるなど，近年エビデンスが構築されて きている一方で, AIP に合併した膵仮性囊胞に対 してはステロイドの有効性を示唆する報告 ${ }^{11 \sim 14}$ は 存在するものの, 未だコンセンサスは得られてい ない。 そこで, 当科および関連施設で診断された AIP 症例のうち, 膵仮性囊胞を合併した 12 症例 の臨床像および経過をもとに, AIPにおける膵仮 性囊胞の形成機序とステロイドの有用性について 
検討した.

\section{対象・検討項目}

2000 年 1 月から 2013 年 10 月の間に当科およ び関連施設で診断された自己免疫性膵炎症例（国 際コンセンサス診断基準 [ICDC] ${ }^{21}$ 確診例） 94 例（男性 75 例, 女性 19 例）のうち, 膵仮性豪胞 を合併した 12 例（12.8\%）を対象とした（Table 1). 男性 11 例, 女性 1 例. 年齢は 61 歳から 71 歳であった. 12 例中 11 例は AIP 初発時に襄胞を 認めたが, 1 例はステロイド導入から 4 年 2 カ月 後のプレドニゾロン (PSL) $5 \mathrm{mg} /$ 日維持療法中に AIP が再燃した際に襄胞が出現した症例であっ た. 膵仮性囊胞出現時, 腹痛を 6 例 (50\%), 黄疸
を 2 例 $(17 \%)$, 体重減少を 2 例（17\%）に認め, 黄疸の 2 例に対しては胆管ステントが留置され た. 9 例 $(75 \%)$ に飲酒歴があり，うち 5 例は大酒 家であった． 2 例 $(17 \%)$ に膀胱癌の既往があり， AIP 発症の 6 年前と 8 年前に治癒切除された. 糖 尿病を合併した 5 例 $(42 \%)$ のうち， 3 例は AIP と同時発症, 1 例は AIP 発症 3 年前に糖尿病と診 断 (食事療法のみ) されており, 1 例は AIP 発症 の 1 年前に糖尿病と診断され，インスリン導入さ れていたが血糖コントロール不良（AIP 診断時 HbAlc 11.0\%) であった. ステロイド開始前に膵 仮性囊胞に対する処置・薬物療法としては, 1 例 で内視鏡的膵管ステント留置, 1 例でオクトレオ チド投与， 2 例で蛋白分解酵素阻害薬投与が行わ

Table 1 患者背景

\begin{tabular}{|c|c|c|}
\hline \multicolumn{3}{|c|}{ Total $(n=12)$} \\
\hline \multicolumn{2}{|c|}{ 性別（男：女） } & $11: 1$ \\
\hline \multicolumn{2}{|c|}{ 年齢 median [range］ } & $64[61 \sim 71]$ \\
\hline \multicolumn{3}{|c|}{ 囊胞出現時期 } \\
\hline \multicolumn{2}{|c|}{ · AIP 初発時 } & $92 \%(11 / 12)$ \\
\hline \multirow{2}{*}{\multicolumn{2}{|c|}{ · AIP 再発時 }} & $8 \%(1 / 12)$ \\
\hline & & ※PSL $5 \mathrm{mg}$ 維持療法中 \\
\hline \multicolumn{3}{|l|}{ 症状 } \\
\hline \multicolumn{2}{|l|}{ ·腹痛 } & $50 \%(6 / 12)$ \\
\hline \multicolumn{2}{|l|}{ ·黄疸 } & $17 \%(2 / 12)$ \\
\hline \multicolumn{2}{|c|}{ ·体重減少 } & $17 \%(2 / 12)$ \\
\hline \multirow{2}{*}{\multicolumn{2}{|c|}{ 飲酒歴（+） }} & $75 \%(9 / 12)$ \\
\hline & & $※ 5$ 例 大酒家 \\
\hline \multirow{2}{*}{\multicolumn{2}{|c|}{ 糖尿病合併（+） }} & $42 \%(5 / 12)$ \\
\hline & & ※3 例 AIP と同時発症 \\
\hline \multicolumn{3}{|r|}{2 例 : 膀胱癌 (治癒切除) } \\
\hline \multicolumn{3}{|c|}{ ステロイド導入前の仮性囊胞に対する特殊治療 } \\
\hline \multicolumn{3}{|c|}{ ・内視鏡的膵管ステント留置 $\quad 1$ 例 } \\
\hline \multicolumn{3}{|c|}{ ・オクトレオチド } \\
\hline \multicolumn{2}{|c|}{ ·蛋白分解酵素阻害薬 } & 2 例 \\
\hline \multirow{2}{*}{\multicolumn{2}{|c|}{ 膵外病変 $(+）$}} & $92 \%(11 / 12)$ \\
\hline \multirow{3}{*}{\multicolumn{2}{|c|}{$\begin{array}{cl}\text { [病変数 }] & 1 \sim 2 \\
& 3< \\
& \text { 部什 }]\end{array}$}} & $58 \%(7 / 12)$ \\
\hline & & $33 \%(4 / 12)$ \\
\hline & 肺門部リンパ節 & $58 \%(7 / 12)$ \\
\hline \multirow{7}{*}{ [部位］ } & 胆管 & $50 \%(6 / 12)$ \\
\hline & 唾液腺 · 顎下腺 & $42 \%(5 / 12)$ \\
\hline & 後腹膜線維症 & $8 \%(1 / 12)$ \\
\hline & 腎臓 & $8 \%(1 / 12)$ \\
\hline & 前立腺 & $8 \%(1 / 12)$ \\
\hline & 間質性肺炎 & $8 \%(1 / 12)$ \\
\hline & 肝炎症性偽腫瘍 & $8 \%(1 / 12)$ \\
\hline
\end{tabular}

PSL : プレドニゾロン, ENPD : 内視鏡的経鼻膵管ドレナージ 
れた. 11 例 $(92 \%)$ に膵外病変の合併を認め, 2 病変以下が 7 例 $(58 \%), 3$ 病変以上が 4 例 $(33 \%)$

Table 2 検査所見 (震胞出現時)

\begin{tabular}{|c|c|}
\hline \multicolumn{2}{|l|}{ Total $(n=12)$} \\
\hline $\operatorname{IgG} 4(\mathrm{mg} / \mathrm{d} l)$ & $365[49.5 \sim 815]$ \\
\hline Level $1 * 1 \quad[271<]$ & $55 \%(6 / 11)$ \\
\hline Level $2 * 1 \quad[135 \sim 270]$ & $36 \%(4 / 11)$ \\
\hline$<135$ & $9 \%(1 / 11)$ \\
\hline $\operatorname{IgG}(\mathrm{mg} / \mathrm{d} l)$ & $1786[1275 \sim 2442]$ \\
\hline $1815<$ & $50 \%(6 / 12)$ \\
\hline Lipase $(\mathrm{U} / l)$ & $101[6 \sim 217]$ \\
\hline $51<$ & $60 \%(6 / 10)$ \\
\hline P-Amylase $(\mathrm{U} / l)$ & $113[7 \sim 320]$ \\
\hline $54<$ & $60 \%(6 / 10)$ \\
\hline 抗核抗体（+） & $27 \%(3 / 11)$ \\
\hline 外分泌機能障害（+ ）*2 & $91 \%(10 / 11)$ \\
\hline BT-PABA $(\%) \quad[n=10]$ & $35.4[5.0 \sim 72.0]$ \\
\hline $70 \%<$ & $10 \%(1 / 10)$ \\
\hline $50 \sim 70 \%$ & $20 \%(2 / 10)$ \\
\hline$<50 \%$ & $70 \%(7 / 10)$ \\
\hline 内分泌機能障害 $(+) * 3$ & $38 \%(3 / 8)$ \\
\hline \multicolumn{2}{|c|}{ 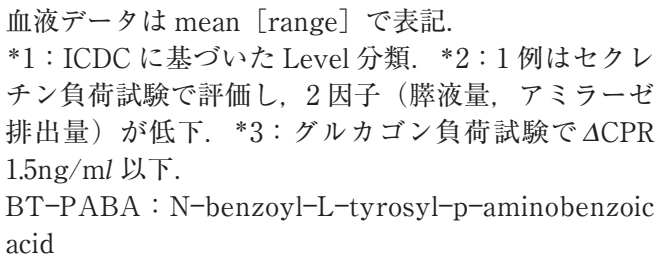 } \\
\hline
\end{tabular}

であった．臓器別では，肺門部リンパ節腫大が 7 例 $(58 \%)$ ，硬化性胆管炎が 6 例 $(50 \%)$ ，硬化性 唾液腺炎・顎下腺炎が 5 例 $(42 \%)$, 後腹膜線維症 腎炎, 間質性肺炎, 前立腺炎, 肝炎症性偽腫瘍が それぞれ 1 例 $(8 \%)$ であった.

上記 12 例における (1)仮性襄胞合併 AIP の特 徴, (2)ステロイド治療による膵仮性囊胞を含めた 画像所見の変化, (3)ステロイド治療の前後におけ る血液生化学的所見や膵外分泌能の変化をもと に, AIP に合併する膵仮性囊胞の形成機序，およ びステロイドの有用性について検討した．なお， 脺外分泌能は BT-PABA（N-benzoyl-L-tyrosylp-aminobenzoic acid）試験・セクレチン負荷試 験, 膵内分泌能はグルカゴン負荷試験, 画像変化 は CT・MRCP・ERCP で評価した. ステロイド 治療前後の血液生化学的所見の比較には Pairedt 検定を用いた。

\section{結果}

(1)-1. 膵仮性囊胞合併 AIP 症例の特徵：血液生 化学的所見, 膵内外分泌機能 (Table 2)

血清 IgG4 は 11 例 中 10 例 $(91 \%), \operatorname{IgG}$ は 12 例中 6 例 $(50 \%)$ で上昇していた. IgG4 に関して は, ICDC level 1 が 6 例 $(55 \%)$, level 2 が 4 例

Table 3 症例一覧：画像所見, 腹痛・膵酵素上昇の有無

\begin{tabular}{|c|c|c|c|c|c|c|c|c|c|c|}
\hline & $\begin{array}{l}\text { 年齢/ } \\
\text { 性別 }\end{array}$ & $\begin{array}{l}\text { 囊胞部位/ } \\
\text { Size (mm) }\end{array}$ & $\begin{array}{c}\text { 囊胞との } \\
\text { 交通 } \\
(\mathrm{ERP})\end{array}$ & $\begin{array}{c}\text { 膵腫大 } \\
(\mathrm{Ph} / \mathrm{Pb} / \mathrm{Pt})\end{array}$ & rim & $\begin{array}{l}\text { 膵管狭細像 } \\
(\mathrm{Ph} / \mathrm{Pb} / \mathrm{Pt})\end{array}$ & $\begin{array}{c}\text { 閉塞性膵炎*1 } \\
(\mathrm{Ph} / \mathrm{Pb} / \mathrm{Pt})\end{array}$ & 腹痛 & $\begin{array}{c}\text { 膵酵素 } \\
\text { 上昇 }\end{array}$ & $\begin{array}{c}\mathrm{IgG} 4 \\
(\mathrm{mg} / \mathrm{d} l)\end{array}$ \\
\hline 1) & $61 / \mathrm{M}$ & $\mathrm{Pt} / 28$ & - & $+/+/+$ & + & $+/+1-$ & $-1+1+$ & + & + & 49.5 \\
\hline 2) & $66 / \mathrm{M}$ & $\mathrm{Ph}, \mathrm{b}, \mathrm{t} / 69 * 2$ & + & $+/+/+$ & + & $+1+1+$ & $-/+/+$ & - & + & 376 \\
\hline 3) & $70 / \mathrm{M}$ & $\mathrm{Pt} / 15$ & + & $+/+/+$ & + & $+1-1+$ & $-/+/+$ & - & - & 348 \\
\hline 4) & $68 / \mathrm{M}$ & $\mathrm{Pt} / 100$ & + & $+/+1-$ & + & $+/+1-$ & $-1-1+$ & + & + & 243 \\
\hline 5) & $64 / \mathrm{M}$ & $\mathrm{Pt} / 20$ & - & $+/+/+$ & + & $-1+1-$ & $-1-1+$ & - & + & 145 \\
\hline 6) & $64 / \mathrm{M}$ & $\mathrm{Pb} / 30$ & + & $+/+/+$ & + & $+1-1-$ & $-/+/+$ & - & + & 273 \\
\hline 7) $* 3$ & $64 / \mathrm{M}$ & $\mathrm{Pt} / 20$ & - & $+/+/+$ & + & $-1+1-$ & $-1-1+$ & + & + & 186 \\
\hline 8) & 73/M & $\mathrm{Pt} / 12$ & - & $+/+/+$ & + & $+1-1+$ & $-1-1-$ & - & + & 579 \\
\hline 9) & 71/M & $\mathrm{Pt} / 17^{* 2}$ & + & $+/+/+$ & - & $+/+1-$ & $-/+/+$ & + & - & $\mathrm{N} / \mathrm{D}$ \\
\hline 10) & $71 / \mathrm{F}$ & $\mathrm{Pb} / 12$ & + & $+/+/+$ & + & $+1+1-$ & $-1-1-$ & + & - & 746 \\
\hline 11) & $62 / \mathrm{M}$ & $\mathrm{Pb} / 18$ & - & $+/+/+$ & + & $+1-1-$ & $-1+/+$ & + & + & 815 \\
\hline 12) & $63 / \mathrm{M}$ & $\mathrm{Pb}-\mathrm{t} / 60$ & $\mathrm{~N} / \mathrm{D}$ & $+1+1+$ & + & $+1+1-$ & $-1+1+$ & - & $+* 4$ & 249 \\
\hline \multicolumn{2}{|c|}{$\begin{array}{l}\text { Total } \\
(\mathrm{n}=12)\end{array}$} & $\begin{array}{c}33.4 \mathrm{~mm} \\
{[12 \sim 100]}\end{array}$ & $\begin{array}{c}55 \% \\
(6 / 11)\end{array}$ & $12 / 12 / 11$ & $\begin{array}{c}92 \% \\
(11 / 12)\end{array}$ & $10 / 8 / 3$ & $0 / 7 / 10$ & $\begin{array}{l}50 \% \\
(6 / 12)\end{array}$ & $\begin{array}{c}75 \% \\
(9 / 12)\end{array}$ & \\
\hline
\end{tabular}

下段の囊胞のサイズは mean [range] で表記.

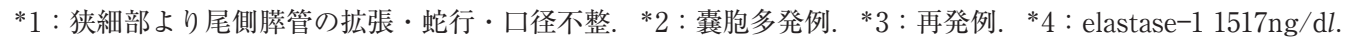

$\mathrm{Ph}$ : 膵頭部, $\mathrm{Pb}$ : 膵体部, $\mathrm{Pt}$ : 膵尾部, $\mathrm{N} / \mathrm{D}:$ not determined 

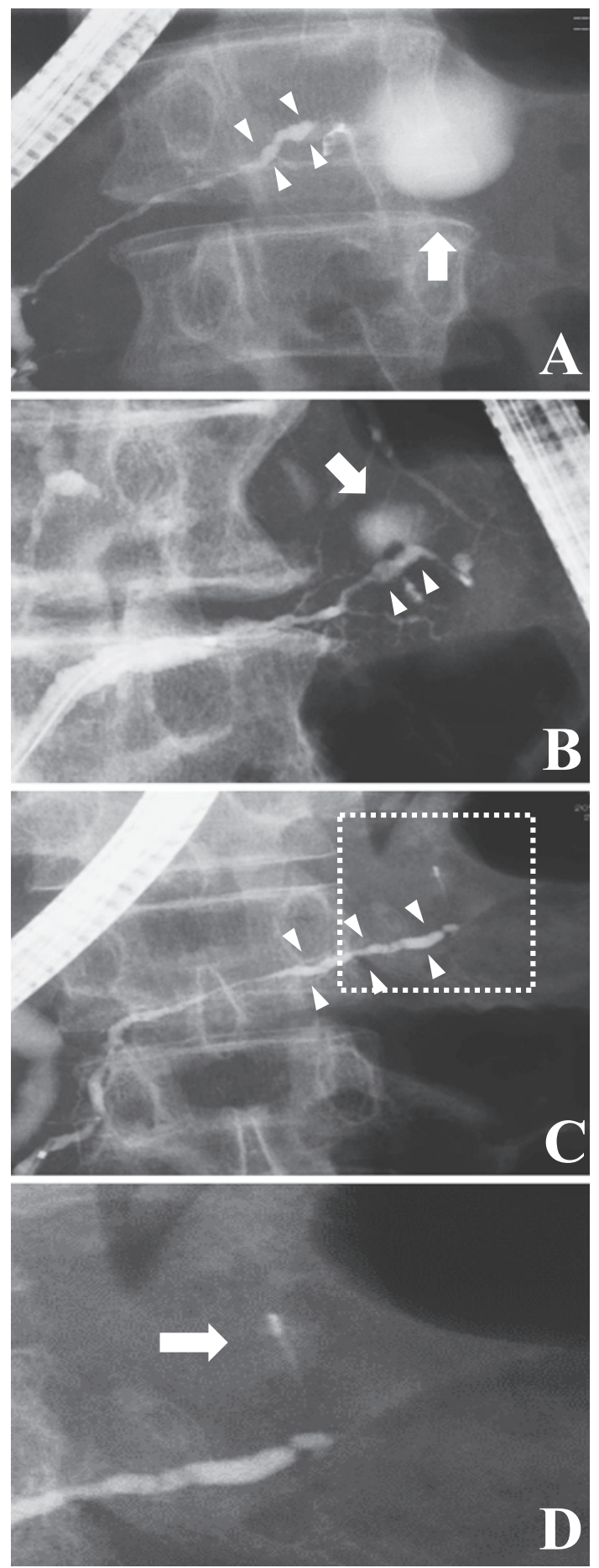

Fig. 1 ERP 画像：囊胞と膵管との交通 症例 2(A), 症例 3(B), 症例 4(C, D) の膵管像. (D) は $(\mathrm{C})$ の枠線部の拡大像を呈示.いずれの症例の膵管像も, 狭細部より上流萃管は拡張・蛇行などの閉塞性膵炎像を呈 しており (矢頭), 仮性囊胞との交通（矢印）を認める.
(36\%), seronegative 症例が 1 例 (9\%)であった. 9 例 (75\%) で血清膵酵素が上昇していた。 なお, 腹痛を認めた 6 例中 4 例で膵酵素が上昇してい た．抗核抗体陽性率は $27 \%(3 / 11)$ であった．脺 外分泌機能は 11 例中 10 例（91\%）で低下してお り, BT-PABA（PFD）試験を施行した 10 例中 7 例で PABA 排泄率 $50 \%$ 以下と重度の外分泌機能 障害を認めた。また，セクレチン負荷試験を行っ た 1 例は 2 因子（膵液量, アミラーゼ排出量）の 低下であった．膵内分泌機能の評価としてグルカ ゴン負荷試験が 8 例に行われ， 3 例 (38\%) で内因 性のインスリン分泌障害 $(\Delta \mathrm{CPR}<1.5 \mathrm{ng} / \mathrm{ml})$ を認 めた（Table 2).

\section{(1)-2. 膵仮性襄胞合併 AIP 症例の特徵：画像所}

\section{見（Table 3)}

内視鏡的逆行性膵管造影 (ERP) を施行した 11 例中 6 例 $(55 \%)$ に膵管と震胞に交通が確認され た (Fig. 1)。膵仮性囊胞のサイズは最小 $12 \mathrm{~mm}$ から最大 $100 \mathrm{~mm}$ と多様であり, 平均值は $33.4 \mathrm{~mm}$ であった．部位に関して，尾部単発 7 例 $(58 \%)$, 体部単発 3 例 $(25 \%)$, 体尾部にまたがる症例が 1 例 $(8 \%)$ と頭部から尾部に多発している症例が 1 例 $(8 \%)$ であり，囊胞は尾部に多い傾向であった (Fig. 2A, C, E). 脺尾部が AIP 診断当初から萎縮 していた 1 例を除いた 11 例 $(92 \%)$ で膵頭部から 尾部までびまん性に腫大しており, 被膜様構造 (capsule-like rim) も 92\%（11/12）と高率に認め た. 膵管狭細像は頭部で 10 例 $(83 \%)$, 体部で 8 例 $(66 \%)$ と高率に認められたのに対し(Fig. 3A, C), 尾部では 3 例 $(25 \%)$ のみであった。一方, 狭細部より尾側膵管の拡張 - 口径不整（＝閉塞性 膵炎)の所見は体部 7 例 (58\%)，尾部 10 例 (83\%) と体尾部に多く(Fig. 3A，C), 囊胞の局在部位と 同様の傾向を示した（Table 3).

(2)ステロイド治療による画像所見・症状の変化 (Table 4)

初発例（11 例）でステロイドが開始, 再発例 （1 例）ではステロイドが増量された. PSL は 0.6 $\mathrm{mg} / \mathrm{kg} / \mathrm{day}$ から開始し，2４週毎に $5 \mathrm{mg} /$ day ずつ減量, 全例で $5 \mathrm{mg} /$ body/day の維持療法が行 われた。 なお, 2 例（症例 4,6; Table 3,4）でス テロイド導入前に蛋白分解酵素阻害薬が投与され 

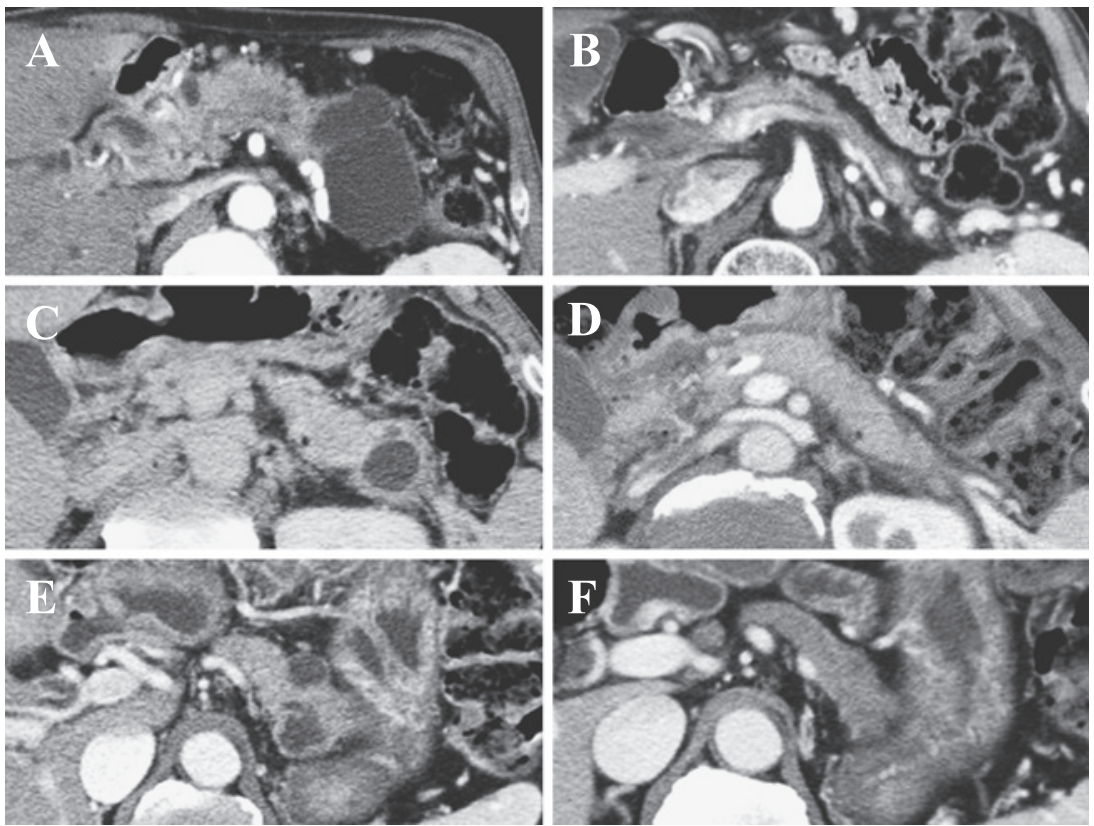

Fig. 2 ステロイド治療前後での画像（腹部 CT）の変化

症例 2 (A ; PSL 前, B ; PSL 後), 症例 7 ( C ; PSL 前, D ; PSL 後), 症例 9 ( E ; PSL 前, $\mathrm{F}$; PSL 後) の腹部 CT 画像. 症例 2 は尾部の囊胞（A）を呈示. 症例 9 は尾部に異胞が 多発（C）していた。囊胞は全例でステロイド治療により消失（B, D, F）した。
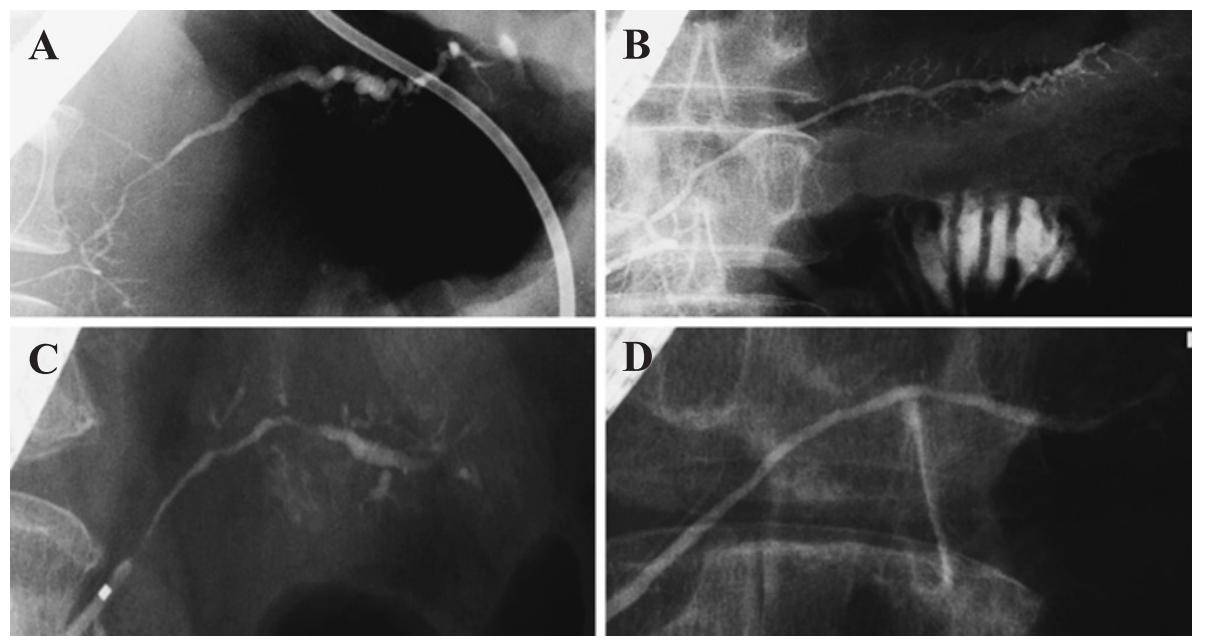

Fig. 3 ステロイド治療前後での画像（ERP）の変化

症例 1 (A ; PSL 前, B ; PSL 後), 症例 5（C；PSL 前, D ; PSL 後) の膵管像. 症例 1 は頭部か ら体部 $(\mathrm{A})$, 症例 5 は体部 $(\mathrm{C})$ に膵管狭細像があり, 上流の主膵管・分枝膵管には不規則な拡 張や蛇行を認める．ステロイド治療後には上記所見はいずれも改善（B, D）した.

ていたが, ステロイド開始（増量）と同時に中止 された。囊胞出現からステロイドが開始(増量)さ
れるまでの期間に関して, 速やかに導入された(最 短 2.4 週)症例も存在する反面, 診断に難渋, ある 
Table 4 症例一覧：治療経過

\begin{tabular}{|c|c|c|c|c|c|c|c|c|c|}
\hline & \multirow[b]{2}{*}{$\begin{array}{l}\text { PSL 投与量 } \\
\text { (mg/day) }\end{array}$} & \multirow{2}{*}{ 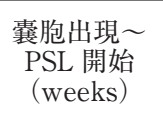 } & \multirow{2}{*}{$\begin{array}{l}\text { PSL 開始 } \\
\text { 囊胞消失) } \\
\text { (weeks) }\end{array}$} & \multicolumn{6}{|c|}{ 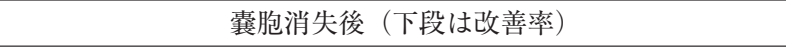 } \\
\hline & & & & 膵腫大 & $\begin{array}{l}\text { 萊管 } \\
\text { 狭細像 }\end{array}$ & $\begin{array}{c}\text { 閉塞性 } \\
\text { 膵炎 }\end{array}$ & 腹痛 & $\begin{array}{c}\text { 膵酵素 } \\
\text { 上昇 }\end{array}$ & $\begin{array}{l}\text { 外分泌機能 } \\
\text { (BT-PABA) }\end{array}$ \\
\hline 1) & 40 & 2.4 & 4.4 & 改善 & 改善 & 改善 & 消失 & 改善 & $\mathrm{N} / \mathrm{D}$ \\
\hline 2) & 30 & 11.9 & 28.1 & 改善 & 改善 & 改善 & $\mathrm{N} / \mathrm{A}$ & 改善 & N/D \\
\hline 3) & 30 & 7.6 & 11.6 & 改善 & 改善 & 改善 & $\mathrm{N} / \mathrm{A}$ & $\mathrm{N} / \mathrm{A}$ & $\begin{array}{c}\text { 悪化 } \\
(22.3 \rightarrow 12.3)\end{array}$ \\
\hline 4) & 35 & $9.0 * 2$ & 8.0 & 改善 & 改善 & 改善 & 消失 & 改善 & N/D \\
\hline 5) & 40 & 3.1 & 49.0 & 改善 & 改善 & 改善 & $\mathrm{N} / \mathrm{A}$ & 改善 & $\mathrm{N} / \mathrm{D}$ \\
\hline 6) & 30 & $41.9 * 3$ & 3.0 & 改善 & 不変 & 改善 & $\mathrm{N} / \mathrm{A}$ & 改善 & $\begin{array}{c}\text { 改善 } \\
(19.9 \rightarrow 73.9)\end{array}$ \\
\hline 7)*1 & 30 & 34.4 & 2.6 & 改善 & 改善 & 改善 & 消失 & 改善 & N/D \\
\hline 8) & 30 & 2.7 & 23.6 & 改善 & 改善 & $\mathrm{N} / \mathrm{A}$ & $\mathrm{N} / \mathrm{A}$ & 改善 & $\begin{array}{c}\text { 改善 } \\
(44.2 \rightarrow 53.6)\end{array}$ \\
\hline 9) & 30 & 41.3 & 5.9 & 改善 & 改善 & 改善 & 消失 & $\mathrm{N} / \mathrm{A}$ & 改善*6 \\
\hline 10) & 40 & 9.4 & 2.0 & 改善 & 改善 & $\mathrm{N} / \mathrm{A}$ & 消失 & $\mathrm{N} / \mathrm{A}$ & N/D \\
\hline 11) & 30 & 19.4 & 14.0 & 改善 & 改善 & 改善 & 消失 & 改善 & $\begin{array}{c}\text { 改善 } \\
(5.0 \rightarrow 20.5)\end{array}$ \\
\hline 12) & 30 & $22.0 * 4$ & 2.1 & 改善 & 不変 & 不変 & $\mathrm{N} / \mathrm{A}$ & 改善*5 & $\mathrm{N} / \mathrm{D}$ \\
\hline Tot: & $(\mathrm{n}=12)$ & $\begin{array}{c}17.1 \\
{[2.4 \sim 41.9]}\end{array}$ & $\begin{array}{c}12.9 \\
{[2.0 \sim 49.0]}\end{array}$ & $\begin{array}{l}100 \% \\
(12 / 12)\end{array}$ & $\begin{array}{c}83 \% \\
(10 / 12)\end{array}$ & $\begin{array}{c}90 \% \\
(9 / 10)\end{array}$ & $\begin{array}{l}100 \% \\
(6 / 6)\end{array}$ & $\begin{array}{l}100 \% \\
(9 / 9)\end{array}$ & $\begin{array}{l}80 \% \\
(4 / 5)\end{array}$ \\
\hline
\end{tabular}

下段の期間は mean [range ] で表記.

*1 : 再発症例。*2：サンドスタチン投与にて PSL 開始前に囊胞が軽度縮小した症例。*3：診断に難渋し，膵管ス テント留置行うも無効であった症例。* 4 ：診断に難渋し， PSL 導入前に襄胞が軽度縮小。 $* 5:$ Elastase $-1(\mathrm{ng} / \mathrm{d} l)$

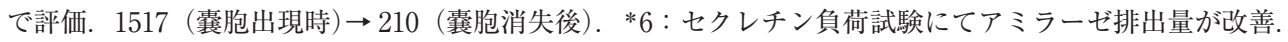

PSL : プレドニゾロン, BT-PABA : N-benzoyl-L-tyrosyl-p-aminobenzoic acid, N/A : not applicable, N/D : not determined

いは合併症の管理によりステロイド導入が遅れた 症例（最長 41.9 週）も存在した。なお，オクトレ オチドを投与した症例（症例 4 ; Table 3,4) と診 断に難渋したためにステロイド開始が遅れた症例 (症例 12 ; Table 3, 4) ではステロイド導入前に 囊胞は軽度縮小したが，それ以外の症例では自然 消退や縮小は認めなかった。

膵仮性囊胞はステロイド治療により全例で消失 した (Fig. 2B，D，F）が，速やかに消失した症例 (最短 2.1 週) も存在する一方で囊胞消失までに長 期間を要する症例（最長 49 週）も存在した。腹痛 は 6 例全例で治療開始後速やかに消失した。囊胞 消失時, 膵腫大は全例, 膵管狭細像は 10 例 (83\%), 閉塞性膵炎像に関しては 11 例 $(92 \%)$ で改善して おり (Fig. 3B, D), ステロイド反応性は良好であっ た.

(3)ステロイド治療による血液生化学的所見や膵 外分泌能の変化

膵仮性囊胞消失後の血清 IgG4, IgG の推移は,
囊胞出現時と比較していずれも有意に低下した (Fig. 4A，B). 血中膵酵素に関しても, 血清リパー ゼおよび脺アミラーゼは全例で囊胞消失後に正常 化した（Fig. 4C，D）。その他 1 例（症例 12 ; Table 3，4）に関してはエラスターゼ 1 で評価し, 治 療前 $1517 \mathrm{ng} / \mathrm{d} l$ から豪胞消失後 $210 \mathrm{ng} / \mathrm{d} l$ と正常 化した. 一方, 膵外分泌機能は, 囊胞消失後に評 価し得た 5 例中 4 例（80\%）で改善を認めた.

\section{考察}

AIP とは「自己免疫的機序が発症に関与する膵 の炎症性疾患」であり, 1995 年に本邦より疾患概 念が発信された ${ }^{11}$, 比較的歴史の浅い疾患である. その後の多数の知見の集積により徐々に詳細な病 態が明らかとなってきている反面, 未だ不明な点 も多い.

AIP の特徴として, びまん性膵腫大 ${ }^{2)}$ や膵管狭 細像)といった画像所見や血清 IgG4 の上昇 ${ }^{4)}$, ま た近年では IgG4 関連疾患として多彩な膵外病変 
(A) IgG4 ( $\mathrm{n}=11)$

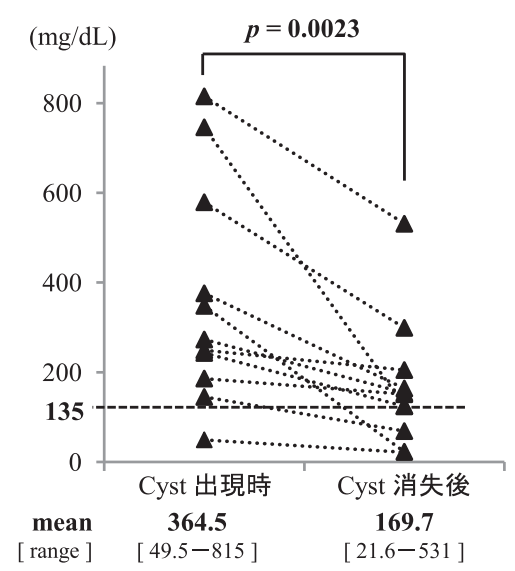

(C) Lipase $(\mathrm{n}=11)$

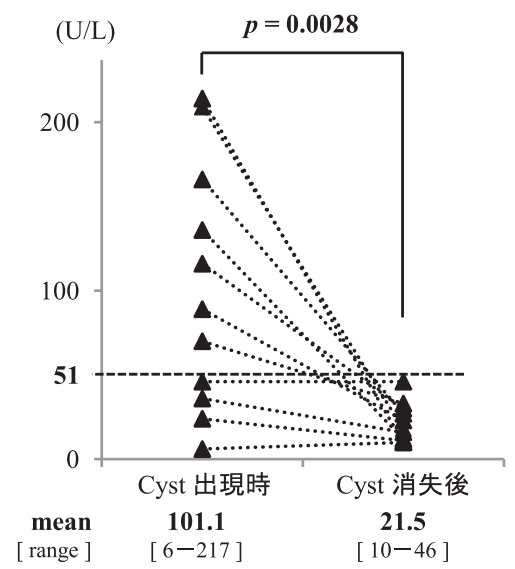

(B) $\operatorname{IgG}(\mathrm{n}=12)$

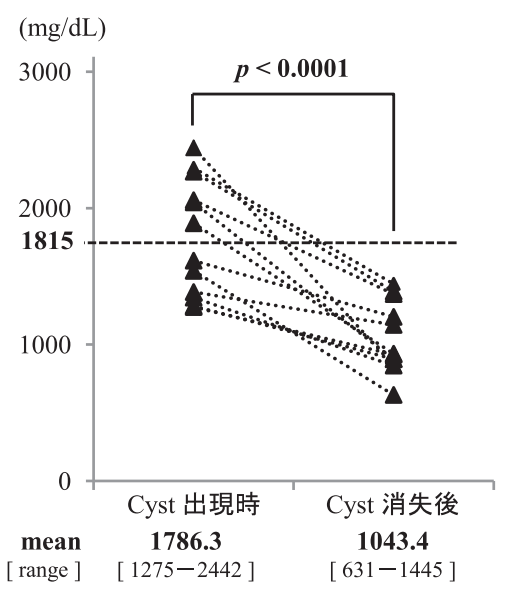

Fig. 4 血液生化学所見の推移

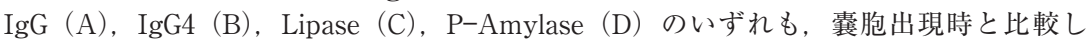
て Cyst消失後（ステロイド治療後）で有意に低下した。脺酔素に関しては全例で正常化 した $(\mathrm{C}, \mathrm{D})$. 治療前後での比較は Paired- $\mathrm{t}$ 検定で行った.

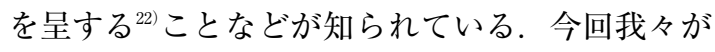
検討した 12 例においても, びまん性の膵腫大 $(92 \%)$ や被膜様構造 $(92 \%), 1 / 3$ 以上に及ぶ脺管 狭細像 $(100 \%)$, 血清 IgG4 の上昇 $(91 \%)$, 膵外 病変の合併 $(92 \%)$ など, AIP に典型的な所見が 数多くみられた.

一方, AIP の疾患概念が発信された当初は「狭 細部位の上流膵管には著明な拡張は伴わず，仮性
囊胞を形成することは稀」1) とされており，2002 年に行われた厚生労働省難治性膵疾患に関する調

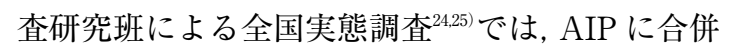
する主膵管拡張と脺囊胞の頻度はそれぞれ $27 \%$, $7 \%$ と報告されている. その後も, 従来の疾患概念 とは異なった「膵仮性囊胞を合併する」AIP 症例 の報告 ${ }^{11 \sim 19)}$ は散見されるものの, その症例数の少 なさから, AIP における膵仮性囊胞の形成機序は 
未だ解明されておらず，有効な治療法に関するコ ンセンサスも得られていない.

AIP と同じく膵管に狭窄病変を呈する慢性脺 炎や通常型膵管癌においては, 狭窄部より上流の 膵管では膵液流出障害（膵液うっ滞）に伴う膵管 内圧上昇から「閉塞性膵炎」を生じ, 尾側膵管の 拡張, 膵酵素上昇, 腹痛発作などを呈する ${ }^{8,23)}$. ま た, 時に主膵管や分枝膵管の破綻をきたし, 永続 的な膵液漏出による限局性液貯留, いわゆる膵仮 性震胞が形成される

今回の我々の検討では, $83 \%(10 / 12)$ と AIP の全国実態調查 24,25$)$ と比較しても高率に狭細部よ り上流の膵管の口径不整や拡張を認め, 同部位に 囊胞が形成される傾向があった。さらに, 腹痛 （50\%）や膵酵素上昇（75\%）といった閉塞性膵炎 の特徵も諸家の報告7 ${ }^{724.25)}$ と比較して高い頻度で認 められ，55\%に膵管と囊胞の交通が確認されたこ とより, 慢性膵炎や通常型膵管癌と同様に AIP においても閉塞性脺炎が起こり, その結果として 膵仮性囊胞を形成したと考えられた。

一般に, 膵仮性囊胞が長期間残存した場合には, 感染, 破裂, 出血といった合併症が問題となるた め, 自然消退が期待できない症例に対しては積極 的な治療的介入が推奨される ${ }^{20)}$. 慢性膵炎に合併 した仮性囊胞に対しては, 膵液産生抑制を目的と したソマトスタチンアナログ(オクトレオチド)の 投与 ${ }^{26)}$, EUS下ドレナージや外科的手術などの有 用性 ${ }^{18}$ が報告されているが, 膵管狭窄に伴う膵液 流出障害がその病態の本質であるため, 近年では 膵管狭窄の解除を目的として経乳頭的なドレナー ジが選択されることも多く27)，2012 年には内視鏡 的膵管ステント留置術が本邦でも保険収載され た。

AIPに合併する膵仮性囊胞に対する治療法に 関して, ステロイドの有効性を示唆する報告 ${ }^{11 \sim 14)}$, および自然消退したという報告 ${ }^{18)}$ も散見される. 今回, 我々の検討では 12 例全例でステロイド治療 により仮性囊胞が消失した。 さらに, 腹痛発作や 膵醳素高值もステロイド投与にて全例で改善して いる. 特に，ステロイド治療前に閉塞性膵炎像を 認めた 10 例全例で膵管狭細像と上流膵管の拡張 が改善しており, 既報 ${ }^{1213)}$ と同様にステロイド治療
により膵液のうっ滞が解除された結果, 囊胞が消 失したと考えられた. 膵外分泌能も $80 \%$ で改善し たことも，AIP に伴う膵外分泌機能低下の一因と 考えられている膵液流出障害 ${ }^{28,29}$ が解除されたこ とを示唆する結果であった. 以上の結果から, AIP に合併した膵仮性囊胞の治療においてはその原 因，すなわち，ステロイド投与により膵管狭細に 起因する膵液流出障害を除去することが重要と考 えられた. また, 内視鏡的治療や外科的切除など の不要な治療を回避するためにも, AIP に膵仮性 囊胞が合併し得ることを念頭に置いたうえで適切 な診断を行わなければならない.

ステロイドを開始するタイミングに関して, 我々の検討ではステロイド導入までの期間に関係 なく全例でステロイドは有効であったが，ステロ イドが投与されなかった症例で膵仮性襄胞が増大 したとする報告 ${ }^{19)}$ や, AIP 発症から囊胞出現まで 長期間が経過した症例ではステロイドが無効で あったという報告 ${ }^{15,16)}$ が存在すること, また自験例 ではステロイド開始前に自然消失した症例が存在 しなかったことから, AIP と診断が確定した症例 ではより早期のステロイド導入が必要と考えられ る.

AIP におけ膵管像の変化は膵管周囲への IgG4 陽性形質細胞を主体とした炎症細胞浸潤や 線維化が原因 ${ }^{5)}$ とされているが, これらの変化によ り膵管の基底膜が破壊される ことも報告されて

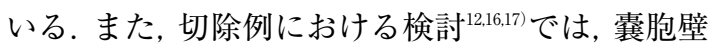
の内腔に膵管上皮細胞は存在せず, その周囲組織 にはAIPによる強い炎症性変化が認められたと 報告されている.今回の 12 例においても襄胞周囲 にはAIPに典型的な画像変化を認めており, AIP による組織変化そのものが限局性の膵液貯留を形 成しやすい素因を含んでいる可能性が考えられ る. また, 多量のアルコール摂取は AIP の膵臓に おける萎縮や膵石形成のリスクファクターである と報告 ${ }^{30)}$ されており，AIPにおいてもアルコール が膵における慢性炎症性変化を増悪させることが 示唆されている. 自験例での飲酒歴は $75 \%$ (うち 大酒家は $41 \%$ ）であり, AIP の全国実態調査 ${ }^{24}$ (27\%) と比較しても高頻度であることから, AIP 発症前にすでに慢性膵炎が存在していた可能性, 
あるいはアルコールによる膵傷害が AIP による 炎症性変化に相乗効果として加わった可能性など も考えられる.

より詳細な病態の解明には, 多数の症例の蓄積 に加えて, 組織学的な検索や膵仮性囊胞非合併 AIP 症例との比較を含めたさらなる検討が必要 である。

\section{結語}

今回, 我々はAIPにおいても閉塞性膵炎が起き た結果として膵仮性囊胞が形成され, その治療に は膵液流出障害の解除を目的としたステロイド治 療が有効であることを明らかにした。膵仮性囊胞 の診療に際しては, その原因疾患として AIP の可 能性も念頭に置いた的確な診断と治療法の選択が 重要である.

\section{文献}

1) Yoshida K, Toki F, Takeuchi $T$, Watanabe S, Shiratori K, Hayashi N. Chronic pancreatitis caused by an autoimmune abnormality. Proposal of the concept of autoimmune pancreatitis. Dig Dis Sci 1995; 40: 1561-8.

2) Ito T, Nakano I, Koyanagi S, et al. Autoimmune pancreatitis as a new clinical entity. Three cases of autoimmune pancreatitis with effective steroid therapy. Dig Dis Sci 1997; 42: 1458-68.

3) Kawaguchi K, Koike M, Tsuruta K, Okamoto A, Tabata I, Fujita N. Lymphoplasmacytic sclerosing pancreatitis with cholangitis: a variant of primary sclerosing cholangitis extensively involving pancreas. Hum Pathol 1991; 22: 387-95.

4) Hamano H, Kawa S, Horiuchi A, et al. High serum IgG4 concentrations in patients with sclerosing pancreatitis. N Engl J Med 2001; 344: 732-8.

5) Ito $\mathrm{T}$, Nishimori I, Inoue $\mathrm{N}$, et al. Treatment for autoimmune pancreatitis: Consensus on the treatment for patients with autoimmune pancreatitis in Japan. J Gastroenterol 2007; 42: 50-8.

6) Kamisawa T, Chari ST, Lerch MM, Kim MH, Gress TM, Shimosegawa T. Recent advances in autoimmune pancreatitis: Type 1 and type 2. Gut 2013; 62: 1373-80.

7) Kawa S, Hamano H. Clinical features of autoimmune pancreatitis. J Gastroenterol 2007; 42: 9-14.

8) Bradley EL 3rd. Pancreatic duct pressure in chronic pancreatitis. Am J Surg 1982; 144: 313-6.

9) Kimura W, Sata N, Nakayama H, et al. Pancreatic carcinoma accompanied by pseudocyst: Report of two cases. J Gastroenterol 1994; 29: 786-91.

10) Wakabayashi T, Kawaura Y, Satomura Y, et al. Clini- cal and imaging features of autoimmune pancreatitis with focal pancreatic swelling or mass formation: comparison with so-called tumor-forming pancreatitis and pancreatic carcinoma. Am J Gastroenterol 2003; 98: 2679-87.

11) Kamisawa T, Anjiki H, Egawa N. Rapid disappearance of a pancreatic cyst after steroid therapy in a patient with autoimmune pancreatitis. Clin Gastroenterol Hepatol 2008; 6: e33-4.

12) Muraki T, Hamano H, Ochi $Y$, et al. Corticosteroid-responsive pancreatic cyst found in autoimmune pancreatitis. J Gastroenterol 2005; 40: 761-6.

13) Nishimura T, Masaoka T, Suzuki H, Aiura K, Nagata $\mathrm{H}$, Ishii H. Autoimmune pancreatitis with pseudocysts. J Gastroenterol 2004; 39: 1005-10.

14) Sohn JW, Cho CM, Jung MK, Park SY, Jeon SW. A Case of Autoimmune Pancreatitis Manifested by a Pseudocyst and IgG4-Associated Cholangitis. Gut Liver 2012; 6: 132-5.

15) Chang KA, Kim TN, Lee SH. Autoimmune pancreatitis complicated by an infected pseudocyst. Clin J Gastroenterol 2010; 3: 168-73.

16) Kawakami H, Kuwatani M, Shinada K, et al. Autoimmune pancreatitis associated with Hemorrhagic pseudocysts: a case report and literature review. Intern Med 2008; 47: 603-8.

17) Welsch T, Kleeff J, Esposito I, Büchler MW, Friess H. Autoimmune pancreatitis associated with a large pancreatic pseudocyst. World J Gastroenterol 2006; 12: 5904-6.

18) Nakazawa T, Ohara H, Sano H, et al. Difficulty in diagnosing autoimmune pancreatitis by imaging findings. Gastrointest Endosc 2007; 65: 99-108.

19) Hirano $K$, Tada M, Isayama $H$, et al. Long-term prognosis of autoimmune pancreatitis with and without corticosteroid treatment. Gut 2007; 56: 1719-24.

20）乾 和郎, 入澤篤志, 大原弘隆, 他. 膵仮性囊胞の内 視鏡治療ガイドライン 2009. 膵臓 $2009 ; 24: 571-93$.

21) Shimosegawa T, Chari ST, Frulloni L, et al. International consensus diagnostic criteria for autoimmune pancreatitis: Guidelines of the international association of pancreatology. Pancreas 2011; 40: 352-8.

22) Kamisawa T, Funata N, Hayashi Y, et al. A new clinicopathological entity of IgG4-related autoimmune disease. J Gastroenterol 2003; 38: 982-4.

23) Costamagna G, Gabbrielli A, Mutignani M, Perri V, Crucitti F. Treatment of 'obstructive' pain by endoscopic drainage in patients with pancreatic head carcinoma. Gastrointest Endosc 1993; 39: 774-7.

24）西森 功, 須田耕一, 大井 至, 小川道雄. 自己免疫 性膵炎の診断と治療 自己免疫性膵炎の実態調査. 膵臓 $2002 ; 17: 619-27$.

25）西森 功, 須田耕一, 大井 至, 小川道雄. 慢性膵炎 自己免疫性萃炎. 日消誌 $2000 ； 97 ： 1355-63$.

26）塩崎道明, 有坂好史, 本合 泰, 他. 膵仮性囊胞に対 
する酢酸オクトレオチドの投与効果についての検 討. 胆と膵 $2004 ; 25: 113-9$.

27) Barthet M, Sahel J, Bodiou-Bertei C, Bernard JP. Endoscopic transpapillary drainage of pancreatic pseudocysts. Gastrointest Endosc 1995; 42: 208-13.

28) Ito T, Kawabe K, Arita Y, et al. Evaluation of pancreatic endocrine and exocrine function in patients with autoimmune pancreatitis. Pancreas 2007; 34: 254-9.
29）李 倫學, 五十嵐久人, 新名雄介, 他. 自己免疫性膵 炎の最前線 自己免疫性膵炎と膵内外分泌機能. 胆 と膵 $2013 ; 34: 725-9$.

30) Hirano $\mathrm{K}$, Tada $\mathrm{M}$, Isayama $\mathrm{H}$, et al. High alcohol consumption increases the risk of pancreatic stone formation and pancreatic atrophy in autoimmune pancreatitis. Pancreas 2013; 42: 502-5.

\title{
Formation mechanism of pancreatic pseudocyst associated with autoimmune pancreatitis and efficacy of corticosteroid therapy: Considerations from 12 cases
}

\author{
Masami MIKI, Lingaku LEE, Hisato IGARASHI, Yusuke NIINA, \\ Masayuki HijıoKA, Keijiro UEdA, Takashi FujIYAMA, Yuichi TACHIBAnA ${ }^{1)}$, \\ Hiroya YAMAgUCHI, Toshihiko SUMII ${ }^{2}$, Ryoichi TAKAYANAGI, and Tetsuhide ITO ${ }^{1)}$
}

Key words: Autoimmune pancreatitis, Pancreatic pseudocyst, Steroid therapy, Obstructive pancreatitis

We investigated the mechanisms of pseudocyst formation in autoimmune pancreatitis and determined the efficacy of corticosteroid therapy by reviewing 12 cases of autoimmune pancreatitis associated with pancreatic pseudocyst. Regarding morphology, all cases presented typical imaging findings such as diffuse enlargement of the pancreas, a capsule-like rim, and narrowing of the main pancreatic duct. Furthermore, 11 out of 12 cases presented elevated serum IgG4 concentrations. In all cases, pancreatic pseudocysts were observed in the pancreatic body and tail. Interestingly, most cases presented with obstructive pancreatitis due to the stricture of the main pancreatic duct, which was associated with abdominal pain and elevated serum pancreatic enzymes. Regarding treatment, corticosteroid therapy drastically improved obstructive pancreatitis, and the pancreatic pseudocysts disappeared. Therefore, we conclude the formation mechanism of pancreatic pseudocyst associated with autoimmune pancreatitis is obstructive pancreatitis due to the stricture of the main pancreatic duct. Corticosteroid administration is an effective therapy for autoimmune pancreatitis and pancreatic pseudocyst.

1) Department of Medicine and Bioregulatory Science, Graduate School of Medical Science, Kyushu University (Fukuoka)

2) Department of Gastroenterology, Kokura Medical Center (Fukuoka) 